\title{
Editorial
}

\section{Whatever became of videotex?}

In the June issue of Information Times (a publication of the Information Industry Association) we note that the Videotex Division of IIA has opted to change its name. It now becomes the Electronic Services Division. The story relays the following:

"This recommendation [for the name change] evolved out of discussions at several Executive Committee meetings where concern has arisen because of the recent fate experienced by consumer videotex systems operator experiments. Unfortunately the word 'videotex' has become synonymous with consumer/home information services, an inaccurate, but nevertheless real perception. Many individuals have expressed an aversion to having their companies and services thought of as 'videotex', to ensure that they are not painted with the videotex brush."

One wonders whether the Videotex Industry Association views this neat little tapdance as a relief from competition or as a harbinger of doom.

If videotex is a conduit for content services, then is online videotex or videotex online?

All of this is relative to a larger point. We have already pointed out (ISU vol. 6 p. 59) the predilection of the information industry to be driven by technology, with examples in downloading, CD-ROM, and videotex. Waiting in the wings we have 'desktop publishing'... . Be sure to sign up for the (inevitable) conference.

A.W. Elias 